\title{
On the correlation of terraces and loesses in Austria
}

\author{
Julius Fink \\ Institut für Geologie und Bodenkunde, Hochschule für Bodenkultur, Wien XVIII/110, Austria
}

Correspondence: Christine Thiel (christine.thiel@bgr.de)

Relevant dates: $\quad$ Published: 17 December 2021

How to cite: $\quad$ Fink, J.: On the correlation of terraces and loesses in Austria, DEUQUA Spec. Pub., 3, 41-59, https://doi.org/10.5194/deuquasp-3-41-2021, 2021.

Special issue statement. This article is part of a special issue published on the occasion of the 70th anniversary of $E \& G$ Quaternary Science Journal (EGQSJ). The special issue celebrates the journal's notable contribution to Quaternary research by revisiting selected milestone articles published in the long history of EGQSJ. The German Quaternary Association (DEUQUA) presents translations of the originals and critical appraisals of their impact in tandem anniversary issues of DEUQUASP and EGQSJ, respectively.

Original article: https://doi.org/10.3285/eg.07.1.07

Tribute: https://doi.org/10.5194/egqsj-70-2212021

Translators: Clare Bamford, Christine Thiel and Henrik Rother

\section{Summary}

The contributions of the field geologists to the knowledge of the Late Pleistocene cover mostly loess-sediments, terraces and moraines; only the two first mentioned sections are dealt with here. ${ }^{1}$

In Austria, the occurrence of the loess is restricted to the foreland of the Alps and the Vienna basin. This region can be subdivided into three subregions (Fig. 1) on the basis of differences in the development of fossil soils, intercalated

\footnotetext{
${ }^{1}$ The lecture given under this title at the DEUQUA conference in Lauffen in 1955 was an abridged version of the present work, which was largely completed at that time, but into which the latest observations are now incorporated.
}

with the loess. An equivalent subdivision applies to recent soils, derived from the Pleistocene loess. These subregions are: the humid western region, the central transitional region and the dry region towards the east. Figure $5 \mathrm{a}$ and $\mathrm{b}$ give summary columns for the humid region, Fig. 5c indicate those for the dry region; no details are submitted for the transitional region. A typical sequence of soils, observed in most sections, might be correlated as follows: in the humid region a bottom-soil (sol lessivé) is covered by solifluction soils ("Fließerde"), whereas in the dry loess region the equivalent is represented by loamy soils ("Verlehmungszone") covered by humus zones with loess intercalations. The respective terms "Linzer" and "Stillfrieder Komplex" are proposed for the sequences in the western and eastern region respectively.

Comparing these sequences in Austria with those of Central and Western Europe, the regional meaning of the sequences outlined is emphasised (Figs. 6, 7, 8).

Regarding the general picture of the terraces, one can discriminate an area "near to the end moraines" (proximal to glaciers; German: "gletschernah") and another "far away from the end moraines" (distant to glaciers; German: "gletscherfern"), the geographical distribution coinciding approximately with the "humid loess region" and the "dry loess region" respectively. For the area near to the end moraines adherence to the nomenclature of A. Penck seems advisable. The Low-Terrace ("Niederterrasse") is locally split up into numerous units, which are of local importance. Only one High-Terrace ("Hochterrasse") is developed; the highest group of terraces belong to the Early Pleistocene (Fig. 9a).

In the area far from the end moraines only one large lowermost terrace ("Prater Terrace") is observed. The terrace im- 
mediately above ("Gänserndorfer Terrace") is morphologically of quite a different type. The distinction towards the next higher steps and likewise among the still higher Early Pleistocene terraces is well developed (see Fig. 9b). For the time being it seems advisable to use for the areas far from the end moraines only a local terminology for morphological units, as the correlation with other areas still deserves further corroboration.

The lowermost (loamy) part of the Stillfried-complex is assumed to coincide with the break between "Prater" and "Gänserndorfer" terrace; the accumulation of humus zones might indicate the beginning of the last "cold" inset, which is accompanied by strong solifluction. This solifluction naturally fades out towards the dry loess region so that humus zones and loess intercalations maintain here their autochtonous character, whereas in the humid loess region this group is represented by thick solifluction soils ("Fließerde").

\section{Article}

For the stratigraphy of the Late Pleistocene three field geological elements are of special importance: terraces, loess and young moraines. In the following work we focus on the first two of these elements; the morphostratigraphic position of the young end moraines will be dealt with only cursorily due to a lack of our own observations.

It is well known that palaeopedological research has experienced an enormous upswing over recent years. Correspondingly, fossil soil formations separating different loess units have been the target of detailed investigations so that many of these formations can now be evaluated stratigraphically as well as typologically. With it, however, the possibility arises to correlate spatially distant occurrences of these soils and to draw conclusions about the respective climatic conditions during their formation. If so far the stratigraphic placement has been still somewhat problematic, then this is only because the regional climatic differentiation - which is valid to the same degree for modern and fossil soils - had not been sufficiently taken into account. The example of the Austrian soils described here, however, shows clearly that, with consideration of these circumstances, typologically different formations can very well be addressed as temporally identical. In recent times, Brunnacker (1954b, 1955) illustrated the climatic differences across the Bavarian and the whole (west) Central European area using a very instructive catena from $\mathrm{N}$ to $\mathrm{S}$.

Such a differentiation can also be presented for Austria (cf. Fig. 1): The Austrian Alpine foothills are relatively narrow, so that a N-S division, similar to the one in the Bavarian region, is only of secondary importance here. However, with increasing proximity to the Alps, a general vertical shortening of the profiles can be observed (which thereby become far more difficult to interpret). A far more distinct differentiation, on the other hand, is observable from $\mathrm{W}$ to $\mathrm{E}$, in that we can separate out a "humid" loess landscape in the $\mathrm{W}$ and a "dry" loess landscape in the E, between which lies a "transitional area". (The latter does not represent a mixture of the forms occurring in both areas, but instead is characterised by particular soils, the importance of which have only recently been properly recognised). In the area of the inner alpine $\mathrm{Vi}$ enna basin the $\mathrm{W}-\mathrm{E}$ classification is again replaced (as in Bavaria) by a N-S arrangement, since at the southern edge between Pitten and Erlach the fossil soils there fully resemble those of the humid loess landscape (compare Fig. 3). Thus, the periglacial (loess) landscape of Austria shown in Fig. 1 is structured as follows (whereby this major division is also valid for the modern (loess) soils):

1. The "humid" loess landscape comprises the entire Alpine foothills up to the area of St. Pölten, as well as the above-described islands at the southern edge of the Vienna Basin and a small transitional zone in central Burgenland, where the gradual transition into the floodplain (loam) area begins (cf. Fink, 1954). Modern soils in the Alpine foothills belong to the Lessive group, partly with minor gley-like alterations. Precipitation is around $700-800 \mathrm{~mm}$.

2. The "transitional area" extends over the border between Waldviertel and Weinviertel, especially to the Kamp Valley and the Krems area, and reaches across the Danube into the Traisen Valley. The modern soils belong in part to the Lessivé group, and partly to the (loess-)brown earths. Precipitation is $600-700 \mathrm{~mm}$, in some places less.

3. The "dry" loess landscape follows to the east and north and is characterised by chernozems in the lower and brown soils in the higher altitudes (from about $200 \mathrm{~m}$ ). Precipitation is mostly below $600 \mathrm{~mm}$.

Profiles of the humid loess landscape can be divided into two groups based on their morphological position (which can be specified precisely in each case): those developed on HighTerrace-gravels and those on sheet gravels. From the first group, four are shown in Fig. 2, the description of which (from left to right) is as follows:

1. Weingartshof. Outcrop at the dip of the High-Terrace SW of Linz, at the feeder road Linz-Bundesstraße Nr. 1; for detailed description see Kohl (1955, pp. 59 and 60 ). Austrian map 1:50000, sheet 32 . Recorded on 3 April 1955 with H. Kohl.

In the area of Linz, the High-Terrace (here Harter Terrace) is particularly well developed. The gravel body is overlain by loess of several meters thickness, the southern edge against the lower terrace (of the River Traun) is, with the exception of several small depressions, very distinctive. Several outcrops, for example at NeuScharlitz, expose only the loamy top of the gravel pack- 


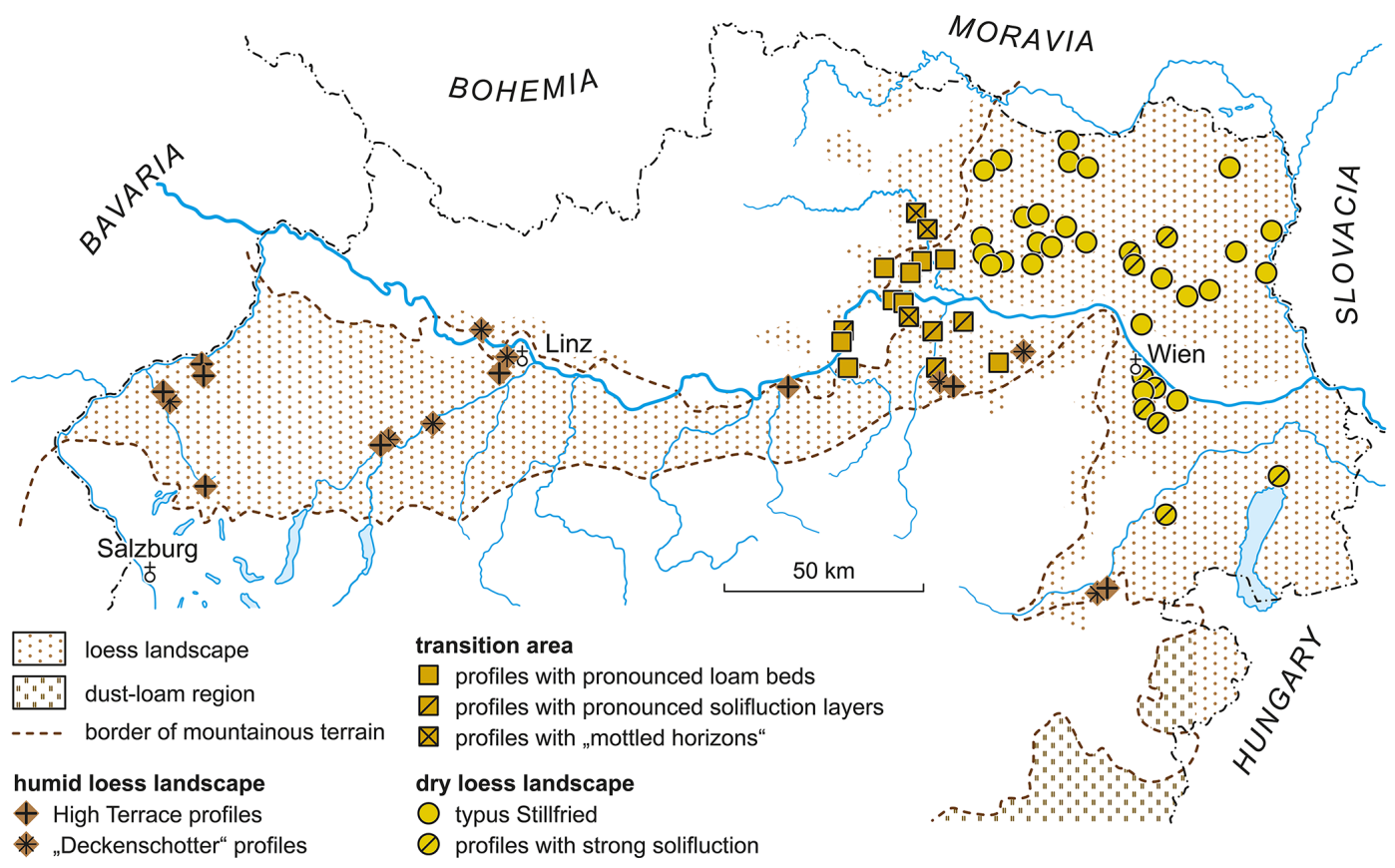

Figure 1. The Austrian loess landscape showing the most important locations of fossil soil sequences.
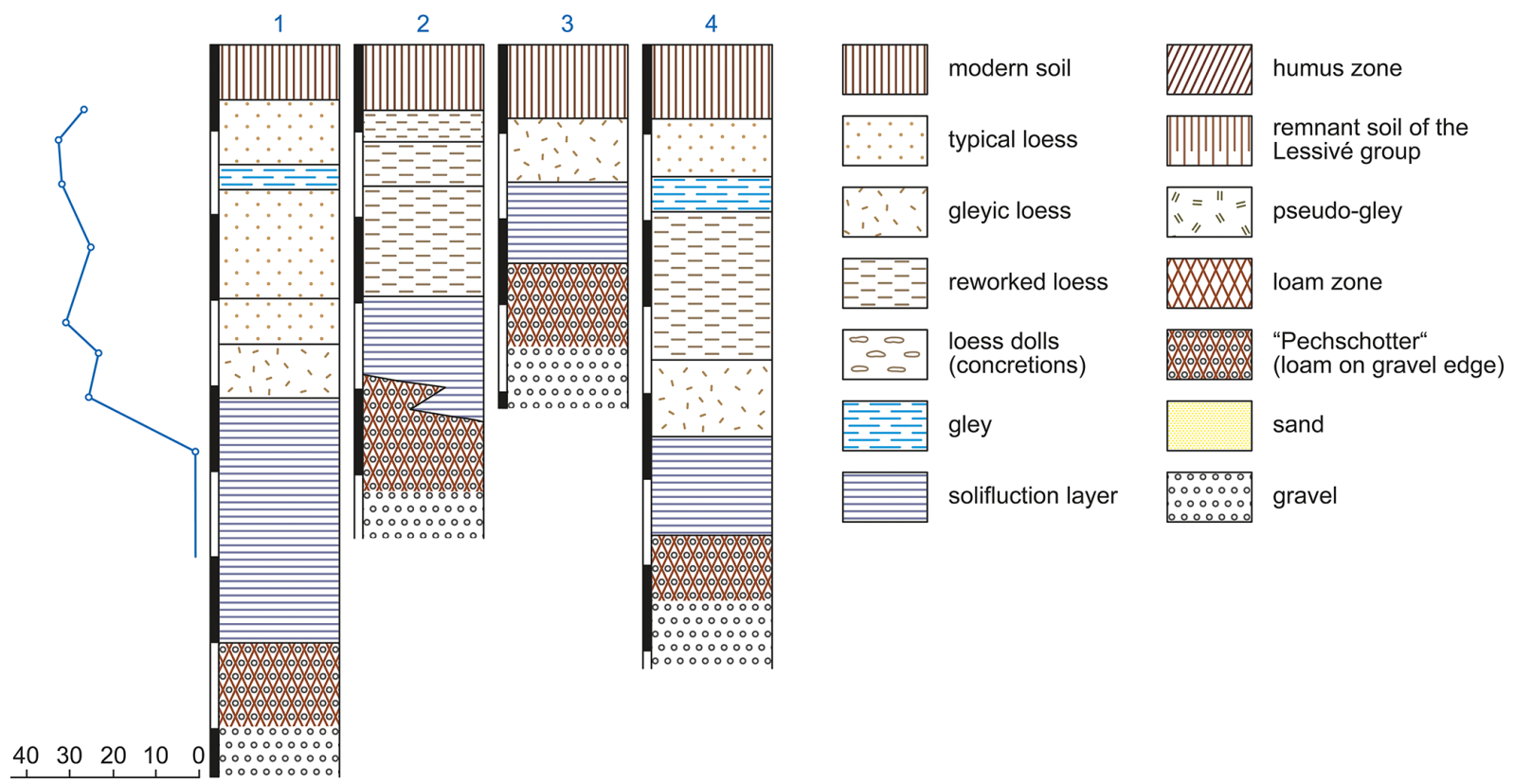

Figure 2. Four High-Terrace profiles of Upper Austria; from left to right: profile Weingartshof (with carbonate curve), Gimpling, Altheim and St. Georgen. More detailed explanations in the text.

age. The profile described here covers the near complete sequence: Above the basal "pitch gravel" (German: "Pechschotter") - which was not exposed at first at this position, but $10 \mathrm{~m}$ to the east during road construction - follows a thick package of lime-free mass flow deposit (layer XII in Kohl, 1955), only slightly humic, but with distinct stratified bedding. The material contains broken (loess) snail shells. Above this, there are various packages of gleyic, calcareous silty fine sand (XI-IX), followed by loess (VIII and VII) and finally tundra gley (VI and $\mathrm{V}$ ), showing varying thicknesses across the profile and cryoturbation features. Particularly instructive is its deformation against the loess (IV) unit above, which also forms the $\mathrm{C}$ horizon for the recent soil (sol brun 


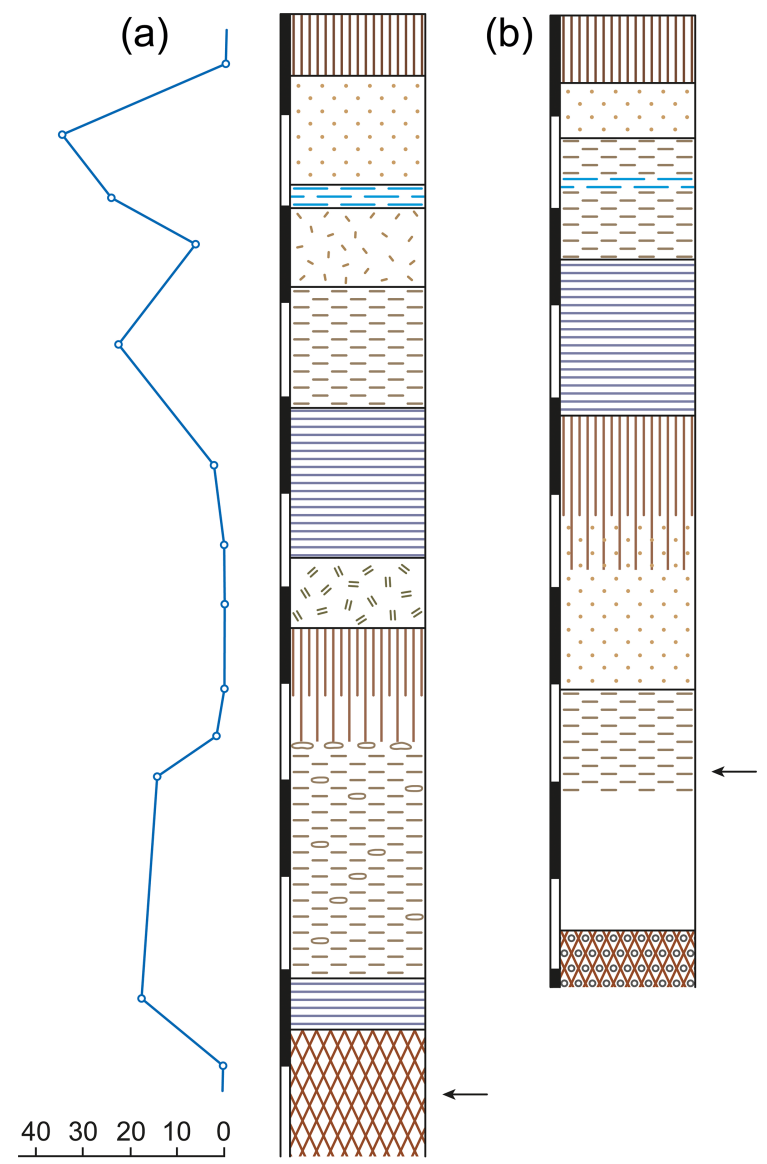

Figure 3. Two profiles of the humid loess landscape showing the complete differentiation. (a) Ziegelwerk Erlach, Lower Austria (with carbonate curve), (b) Ziegelwerk Linz - Grabnerstraße. The small arrows indicate the current base of the quarry walls.

lessivé). The profile stands out - compared to the other outcrops shown in Fig. 2 - due to its particularly thick solifluction layers. This can be explained by a small depression in which the gravel lies deeper and (especially the basal) surface layers are of greater thickness.

2. Gimpling, east of Mühlheim/Inn. Austrian map 1: 50000 , sheet 28 . Recorded on 28 November 1954 with L. Weinberger.

The High-Terrace (River Inn) at this location drops steeply by more than $25 \mathrm{~m}$ towards the low-terrace, strongly subdivided by flat-bottomed valleys with steep valley sides ("Kastentäler"; see Weinberger, 1954). The overlying strata are not particularly typical in their succession, since solifluidal deformation affected all strata. Already the colour of the $1 \mathrm{~m}$-thick loamy zone near the gravel surface is less intense (10 YR 6/6), because the soil has been partially redeposited. Above this lies a solifluction package with embedded pebbles, followed by alluvial loess, again containing some pebbles and dotted gley concretions. The three-part structure shown in the figure is somewhat problematic. Deformations are intense, the alluvial loess contains, at least in part, (redeposited) soil material, so that the boundary against the solifluction layer could also be drawn a little higher; the uppermost part contains pieces of charcoal. The modern soil belongs to the Lessivé group.

There is no gleyic soil present in the profile.

3. North of Altheim. Same map sheet and date of recording as (2).

The above-described High-Terrace (River Inn) is cut off by the River Aschbach, on whose SW-facing slope we find a gravel pit. The surface layers are difficult to access because the gravel package is deeply exposed: Above the weathered terrace gravel (= German: "Pechschotter") follows a package of brown-coloured, somewhat humic loess showing a clearly stratified structure (solifluction layer), followed by a (strongly silty) gley including charcoal residues, on which the modern soil (sol lessivé) rests. The pronounced tundra gley is to be found in the gley package.

4. St. Georgen in the Mattig valley. The gully leading vertically from the village to the High-Terrace (Bergfeld) has produced outcrops on the left and right that have already been described by Weinberger (1953 and 1955), Austrian map 1:50000, sheet 46; taken on 27 November 1954 and 2 April 1955 with L. Weinberger.

The morphological position is the same as at Altheim. Again, the High-Terrace of the River Inn is reduced to a spur by a tributary (this time the River Mattig). Both margins, towards the River Inn as well as SW towards the Mattig valley, are dissected by impressive periglacial valley formations. The outcrop itself shows the clearest sequence in the area of the Inn-HighTerrace:

Above the basal pitch gravel with a strong replacement zone (layers X and IX in Weinberger, 1955), there are (as below) calcareous-free solifluction deposits (VIII), which gradually change into gleyic-loess with a weakly laminated structure (VII). There is no clear boundary to the following thinly laminated, also gleyic (alluvial) loess (VI-IV). The tundra gley (layer III) stands out clearly, in the loess (II) above the modern soil is developed (again from the Lessivé group). A slight gleyification is common to the illuvial horizon of all modern soils in this area.

The profiles at Weingartshof and St. Georgen were part of the excursion program during the DEUQUA field trip across Austria in 1955.

For the second group of loess profiles within the humid loess landscape (those not directly resting on High-Terrace gravels) the two outcrops shown in Fig. 3 were selected as examples. The comparison of the two profiles will be limited to 
their soil typologies and sequences of fossil soils. The morphological position of both profiles (see following text) is not directly comparable.

1. Schranz brickworks, Erlach, N.E. Austrian map 1: 50 000, sheet 106; recorded on 13 June 1955.

The Leitha forms the S and E rim of the Steinfeld, the southernmost part of the Vienna Basin, towards the Wechsel and Rosalien Mountains. Along the right bank only few narrow terraces are nestled against the crystalline; they attain greater importance only south of Neunkirchen and south of Erlach. In the latter section lies the outcrop described here. Usually it is only one terrace, which is overlain by thick loess (partly more than $10 \mathrm{~m}$ ) also showing frequent morphological depressions. The mapping of the southern Vienna Basin is not yet complete. Nevertheless, it can already be said that the gravel body, which is mostly only thinly developed and occurs morphologically mainly in the crystalline areas, is likely to correspond at least to the Middle-Terrace. The excavation base (at the lower end of the depicted profile) does not represent the top of the gravel, which lies several meters deeper, as indicated by a well drilling and the statements of the drill workers. The basal soil formation seems to be particularly thick (several meters), but it corresponds to local alluvial deposits. There is no realistic option of a meaningful comparison to other profiles, because smaller outcrops (ENE Erlach, near Ofenbach) show only a zone of loam, which nevertheless corresponds to the intermediate soil of the Erlach profile.

The profile is exposed at the section to the west of the road to Bromberg and shows the following sequence:

0-60 cm Modern soil, brown earth; carbonate value $0.56 \%$, colour value of the $B$ horizon 10YR 4/3.5.

60-175 Sandy loess with very few linings in the capillaries, nevertheless, carbonates $37.7 \%$, colour value 10 YR $6 / 3$.

175-200 Loess with dotted iron moulds and partly faint gley stains, $24.07 \%$, colour value 10YR 6/3-2.5YR 6/3.

200-285 Sandy loess, similar to layer 2, towards the bottom occasional small iron moulds, occasional charcoal pieces, carbonates $6.4 \%$, colour value $10 \mathrm{YR}$ $6 / 4$, very gradual transition into next horizon

285-415 Dissolved loess. Represents the transition to the solifluction deposits underneath. Here, however, for the time being only layered loess material, carbonate value $22.6 \%$, colour value $10 \mathrm{YR}$ $6 / 3.5$.
415-570 Solifluction deposits (extinguished humus zone material), in the centre of the package the beginnings of a "mottled horizon" (not shown in the figure); carbonates $2.45 \%$, colour value 10YR 4/3;

570-640 gley-like altered (in-situ) soil, in transition towards the top solifluction deposits, two crotovinas, filled with loess (!), here even more "granular" structure, then strongly pronounced, sharpedged blocky structure, aggregate surfaces with manganese coatings, but also pale patches; sporadically intercalated gravel (crystalline material); carbonates $0.5 \%$, colour value (mixed colour) 7.5YR 5/6, gradual transition into next horizon

640-770 lowest part of the no longer gley-like altered subsoil of a sol lessivé, loess structure still clearly recognisable, in the upper part still strong clay coatings on the blocky aggregates, towards the bottom only along large, diagonally crossing shear cracks; carbonates $0 \%$, colour value (mixed colour) 10YR 4/3

770-1010 Alluvial loess beginning with a sharp break (loess doll layer), large loess dolls intercalated at random, carbonates $14.5 \%$, colour value 10YR 6/3.5.

1010-1060 Solifluction deposits from the material of the underlying soil, slight humus colouration. Carbonates $17.4 \%$, colour value 10YR 4/3-7.5YR 4/3

From 1060 until The base: clay zone, sharp-edged blocky structure, sporadic crystalline material in gravel size, very light (gleylike) concretions. Carbonates $0.3 \%$, colour value 7.5 YR 4/3.

2. Ziegelwerk Feichtinger, Grabnerstraße, Linz, Austrian map 1:50 000, sheet 32. Recorded on 14 April 1954.

Several older terraces are cut into the crystalline formations of the Kürn Mountain west of Linz. An exact classification has not yet been made. On the ascent of the road from the train station Untergaumburg towards NW an outcrop appears on the right-hand side, which shows several meters of thick sheet gravels, featuring an intense red colouration, overlying strongly weathered pearl gneiss. These units, in turn, are followed by old loess, which is strongly influenced by gleyic processes including strong bleaching of the coarse prismatic aggregates. In a roughly horizontal continuation of the gravel package, further uphill, lies the brickyard, which, especially in the central part (currently being excavated), shows the structures reproduced in the figure. A detailed description is also available in Kohl (1955, Table IV). However, this corresponds to a wall section further to the left, where a greater differentiation is possible and also solifluidal deformations can be observed. 
The thick fossil soil of the sol lessive type, starting at $420 \mathrm{~cm}$, whose transition into the underlying loess is very instructive, is striking. There are clay coatings around the blocky aggregates (up to several $\mathrm{mm}$ ) and along shear cracks that intersect each other obliquely. Equally striking is the thick package of solifluction deposits, the transition of which into the in-situ soil is only indicated by a different structure and texture. The overlying layer of alluvial loess (which is more or less gleyic) contains a band that resembles a tundra gley, but an exact delineation is not possible. Only in the uppermost parts a typical loess follows, in which the modern soil is developed (sol brun lessivé). The deeper layers of the profile are not accessible. Up to the bottom of the excavation, sandy alluvial loess can still be found; according to the foreman, two meters below this unit follows already the pitch gravel which can thus be paralleled with the one from the outcrop described above.

Various fossil and archaeological finds have already been made along the large excavation walls. According to an oral report, a mammoth tooth currently preserved in the Linz State Museum (locality label Reisingbauer Brickyard) was found in the loess under the (autochthonous) soil, about $1.5 \mathrm{~m}$ above the excavation floor. A scraper, now also in that museum, was recovered from near the base of the solifluction deposits (Dr. Schadler, personal communication). Finally, several Bronze Age pit dwellings were built into the modern soil.

It is not surprising that in the humid loess landscape, where the disturbance of the surface was generally stronger, especially by mass movements, the number of not "typical" profiles, i.e., those outcrops which are far less suitable for evaluation, is significant. Besides the outcrops visited by the DEUQUA excursion, such as the brickyards at Stadion Linz (described by Kohl, 1955) and at Bosch near Mauerkirchen (described by Weinberger, 1953, 1955), a further instructive example is found at the brickyard Würzburger south of Wels, whose west-facing excavation wall is shown in a schematised drawing in Fig. 4)

The brickyard Würzburger (Austrian map 1:50000, sheet 49, recorded on 16 July 1955) lies directly behind the steep slope of the Traun-Enns plate ("Deckenschotter") against the River Traun, which has strongly undercut here on the right bank, meaning that no younger terrace remains could be preserved here. The upper boundary of the covering gravel terrace (and presumably also the upper boundary of the gravel itself) is completely flat, so that the effect of backwater can be observed in almost all surface layers. Nevertheless, an interesting micro-relief characterises the fossil soils, which was exposed along the excavation wall: The basal soil thickens towards the left and right end of the excavation to an intensely blue coloured (groundwater) gley. The overlying packages of solifluction deposits and alluvial loess evens out the surface relief, while the tundra gley, which has a "normal" thickness of about $2 \mathrm{dm}$ at the ends of the excavation wall (see schematic profile Fig. 3, which corresponds to the right corner), grows to a $1 \mathrm{~m}$ thick (groundwater) gley in the middle of the excavation wall. The uppermost loess blanket mantles this micro relief. A very slight depression remains, in which the modern soil (a sol lessivé, partially gleyed) shows a strongly developed illuvial horizon there.

If we now summarise the profiles of the humid loess landscape into two collective profiles, we obtain the sequences shown in Fig. 5a and b. In the following we disregard special pedological details, because these are discussed in a separate article (Fink, 1956).

We are justified in equating the gley soil with the solifluction deposits. In the High-Terrace profiles, below the solifluction deposits follows the pitch gravel ("Pechschotter"), the loamy zone near the top of the gravel dates to the last interglacial. Within a continuous and complete profile the pitch gravel corresponds to the lowest part of an in-situ soil, which is morphologically identical with those modern (loess) soils that have become known from Belgium over recent times (Dudal, 1953). There such remains of soils from the Lessive group are referred to as terre á briques. The latter and the pitch gravel correspond to one stage of formation, the solifluction deposits (in both cases) to a subsequent one. However, since the sequence is always the same, and the forms do not genetically belong together, I propose for them the name "Linz Complex", since these phenomena are well recognisable in the various outcrops of the Linz area. Pitch gravel and solifluction deposits represent only site-related modifications. The two interglacial forms are strictly substrate related: Such a pattern, with changes across minor distances, similar to the situation in Linz, has already been known from other places. Examples are Pettenbrunn, east of St. Pölten (still unpublished), where change occur over few meters, Ofenbach, $3 \mathrm{~km}$ away from Erlach, and finally within the two outcrops of St. Georgen and Mauerkirchen, which were of special interest during the DEUQUA excursion (compare Weinberger, 1953, 1955). However, this variability is easily understood: On drier positions within the otherwise humid loess landscape strong summer dehydration and consequent iron release are observed, as is known from Mediterranean soils, and is common in the dry loess landscape. Already Troll (1926) had used this argument against the Krauss "blood loam theory". Thus, it belongs to the characteristic of the humid loess landscape that loamy zones of interglacial age (with their own red colouration) are found only in the upper portions of the gravels.

A few words about the soils lying stratigraphically below the Linz complex: Reporting general features is difficult because they are in the main structurally disturbed and, fur- 


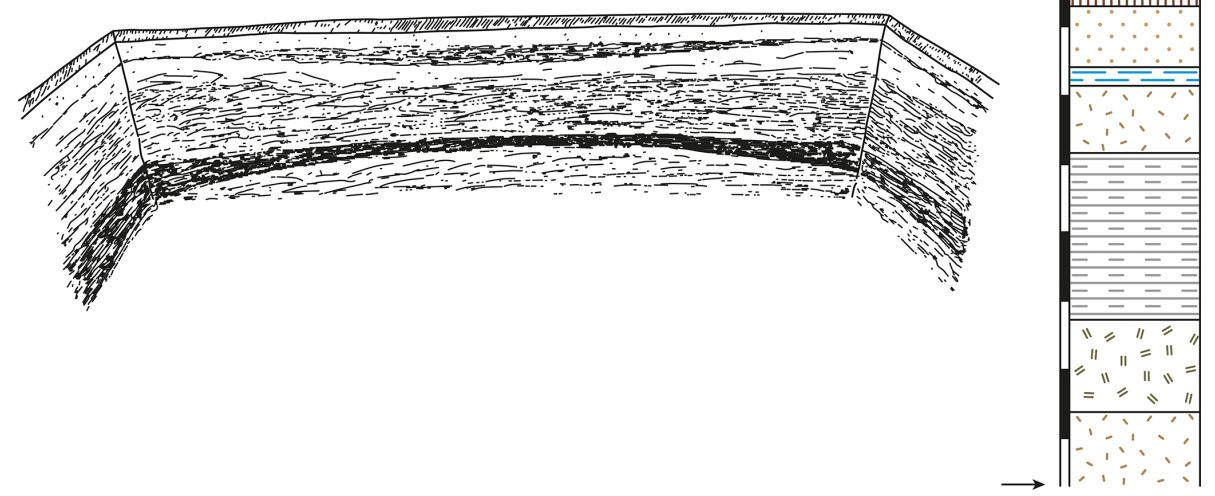

Figure 4. Brickyard Würzburger south of Wels (Aschet), Upper Austria. The excavation wall shown in the drawing is highly exaggerated. On the right, schematic profile of the right (northern) end of this wall.

(a)

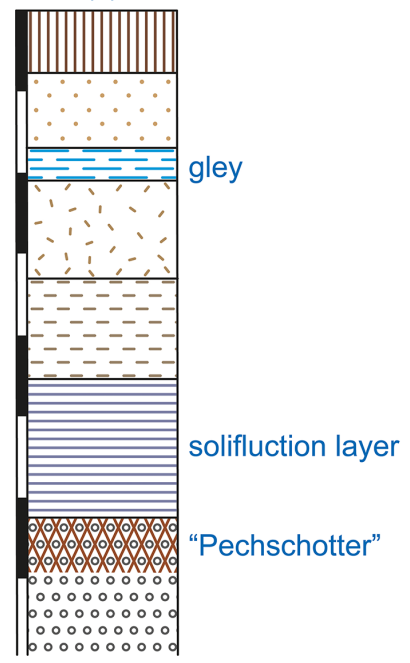

(b)

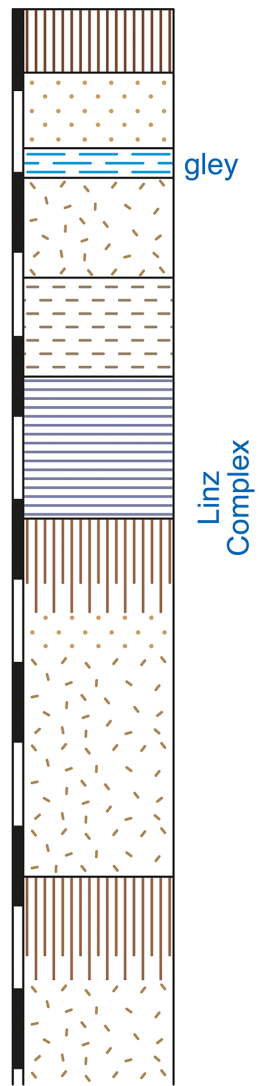

(c)

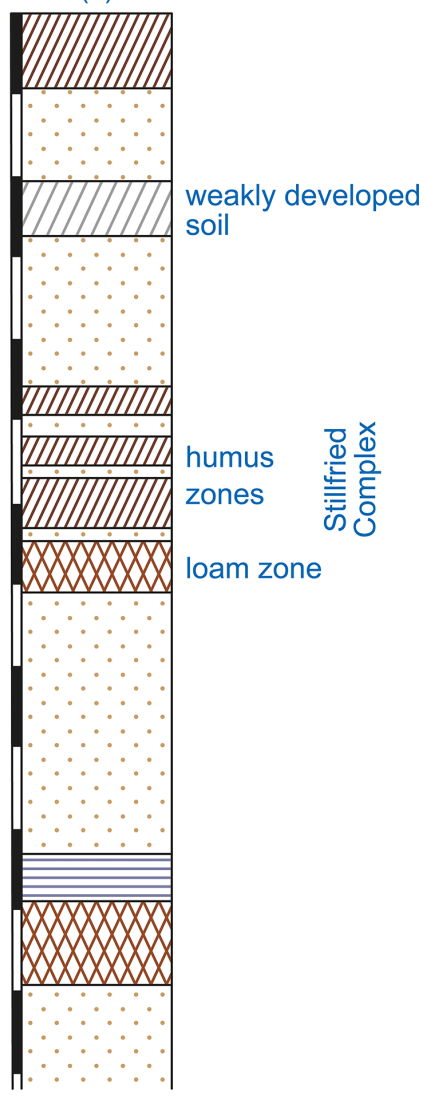

Figure 5. Collective profiles for the Austrian loess landscape; (a) idealised profile summarising High-Terrace profiles of the humid loess landscape; (b) collective profile for the humid loess landscape resting on older formations; (c) collective profile for the dry loess landscape.

thermore, there are not many outcrops where these strata are exposed. Typologically they are almost always gleyic soils, and also the loess under the Linz complex usually shows gleyic features. Where the sheet gravels come to the top, we find loamy zones within the gravel tops similar to the pitch gravel, although these units are thicker than those of the pitch gravel. As examples for this, Linz - Grabnerstraße, but also brickyards Bosch and Raschhofer (Weinberger, 1953) can be cited.

Figure 5c compares the two idealised profiles of the humid loess landscape with those of the dry loess landscape. For the dry loess landscape, detailed descriptions of indi- 
vidual outcrops may be omitted here, since they are already available in larger numbers, for example in Brandtner (1954) and Fink (1953, 1954, 1955a). In the profiles of the dry loess landscape the loess is very rarely influenced by gleyification or solifluction phenomena (and if they are of topogenic origin), has a straw-yellow colouring, high carbonate content, and a typical structure (filling of the capillaries by calcite) and fossil soils embedded within the loess are well preserved.

A distinctive sequence of directly overlying soils can always be identified: at the base a loamy zone, with an underlying Ca-horizon, directly above it, or separated by a thin band of loess, follow one or more humus zones (in case of several humus zones these are again separated by intermediate loess layers). I have named this sequence "Stillfrieder Komplex"2 based on the locality Stillfried at the River March (visited on the DEUQUA excursion in 1955). The term "complex" is due to the observations that, as is the case with the Linz complex, there is a sequence of successive soil forms. Again, the pedological details need not be discussed here, as they have already been dealt with elsewhere (Fink, 1956). However, it must be emphasised once again that it is not a question of one, but of several temporally successively developed formations. Unfortunately, the Czech palaeopedologists, who have much more instructive sequences than we have here on our dry loess landscapes, consider this to represent a single uniform soil (compare Musil and Valoch, 1955, who even draw ice wedges filled only with humic material penetrating into the brown horizon. With a uniform soil, however, a mixing would have to occur!).

Above the Stillfried complex, separated by a thick unit of loess, follows a very pale soil formation, which I have tentatively named "Stillfried B". From the carbonate curve (Fink, 1955b; Fig. 10) it is clear that this is an autochthonous soil with an underlying Ca horizon. Above "Stillfried B" follows a (not very thick) loess package, in which the modern soil, in most cases a chernozem, is developed.

The soils below the Stillfried complex are often intensely coloured loamy zones. Brandtner (1954) worked out the differences compared to the loamy zones of the Stillfried complex, and I completely agree with him on this matter. It is important to point out that those deeper loamy zones usually end with a package of solifluction deposits or alluvial loess.

The parallelisation between humid and dry loess landscapes is self-evident (compare Fig. 5). The thick solifluction deposits of the Linz complex correspond to the humus zones (with intermediate loess layers) in the dry area. Here the solifluction - in the sense of Büdel (1949) at the onset of a glacial period - could only become effective at very

\footnotetext{
${ }^{2}$ Brandtner (1954) named the same sequence after another locality as the "Fellabrunn soil complex", mainly because based on his stratigraphic interpretation it falls within the F-interglacial. However, the locality is actually called Oberfellabrunn, and additionally he himself refers to the outcrop Stillfried at the River March as the "ideal profile" in the text to his Fig. 4.
}

favourable sites, so that the first accumulated loess could still develop chernozems soils (humus zones), which were interrupted in their formation again by the accumulation of further loess etc., until finally the pure loess accumulation began. The transition took place very gradually, as shown by crotovinas and intense earthworm activity in the top of the (uppermost) humus zone. This change from "humus zone time" to "loess time" corresponds in the humid loess landscape to the change from gleyic loess and gley loess to typical loess. Obviously, the humid soil of the humid landscape may now also be paralleled with the pale soil above the Stillfried complex. Brunnacker (1955b) did this in a similar way by equating the humid soil with the "brown weathering horizon". Thus, all these forms seem to have a stratigraphic value, even if the last word is not yet spoken on the typological naming; this is especially true in our area, because the number of profiles with Stillfried B is still very small.

It is not easy to include the forms of the "transitional area" as shown in Fig. 5 into this established correlation. However, most of the loess profiles with prehistoric content are located in this area. Furthermore, Götzinger $(1935,1936)$ has derived the "Göttweig Soil" and the "Paudorf Soil" from here. (On the other hand, Götzinger, 1935 had deliberately given his "Hollabrunn humus zone", which is identical with the Stillfried complex, its own name, even if he had equated it temporally with the Göttweig Soil; for the forms of the dry landscape and the transition area are very different). For the Göttweig and Paudorf soils it is true that the respective locus typicus is not very favourable. In the case of Paudorf - see the description in Fink (1954) - a terrace-morphological differentiation is impossible; for the other case this still needs to be accomplished first. After completion of the geological reconnaissance by R. Grill (for the Krems sheet) this will certainly be possible. For the time being, only the complicated situation in the hollow way west of Furth (north of Göttweig) is pointed out. There a loess strip is sandwiched between the top of the gravel and the loess zone but only in some places; furthermore, the gravel body itself shows a lot of local solifluction material alongside the deeper lying and more distantly sourced gravel. Götzinger's $(1935,1936)$ stratigraphic interpretation of both the gravel and the loess zone is therefore very problematic.

One may characterise the transitional region provisionally as a space, in which predominantly soils similar to the dry area developed; above all, the thick loamy zones are striking. However, the early glacial overprinting proceeded completely in the sense of the humid loess landscape in the transition area. Therefore, some profiles are characterised by thick solifluction deposits, which are more intensely coloured than in the humid area, and thus really represent extinct humus zones (e.g. Thallern, Pottenbrunn, also Wielandsthal and others). Other traces of frost action are also very frequent, e.g., "mottled horizons"; these consist of humus zone and loamy zone material, sharply separated from each other in $2-3 \mathrm{~cm}$ large chunks (cf. Fink, 1954). The Paudorf Soil at the lo- 
cus typicus consists only of such a mottled zone (with an underlying Ca horizon), which is identical to the upper fossil soil at Stiefern and Buchberg am Kamp. Typologically the concept of the "Paudorf Soil" is therefore to be justified, however, its stratigraphic usefulness must for the time being be doubted. In the middle of the dry loess landscape, due to special topographic circumstances, we also find the appearance of mottled horizons in the Stillfried complex, which is, however, more fragmented. (These are the profiles in which the solifluction could become effective, while it otherwise recedes in the dry loess landscape, at least in the zone downward of the Stillfried complex. Thus, in Weinsteig and also in Wetzleinsdorf (Fink, 1954) these mottled horizons were found in the middle of the more diluvial package above the loess zone (thus the equivalent of the humus zones) at places of a particularly pronounced micro-relief, while in Paudorf they are supposed to represent a stratigraphic horizon).

Therefore, the following distinctions were made for the transitional area in Fig. 1: (1) profiles with pronounced zones of loamy soil, such as at the classic profiles Krems-Hundsteig and Krems-Schießstätte, (2) profiles with pronounced mottled horizons, and (3) profiles with strong solifluction packages. This distinction is purely typological and has for the time being no stratigraphic consequences.

It should now be permissible to highlight the regional importance of the Stillfried or Linz complex. If at the beginning a comparison with profiles from North Württemberg (Germany) is made, it is because this area became known due to the exemplary survey of Freising $(1951,1953)$. He correctly recognised the solifluction deposits and their stratigraphic position, as well as the importance of the (uppermost) tundra gley. Palaeopedological research has thus made a great step forward. Therefore, for the profile of Böckingen near Heilbronn shown in Fig. 6, the description of Freising (1953) shall only be supplemented by carbonate and colour values. For the different layers the designations are the same as used in the Austrian profiles. The Arabic numbers in parentheses indicate the horizons separated out by Freising (1953):

In general, it can be said that the upper parts of the profile (up to zone II) correspond perfectly with the profiles of our humid loess landscape (cf. Fig. 5). Minor modifications are given by a stronger tundra gley, furthermore by the occurrence of crotovinas above the solifluction deposits (or better in the transition of the solifluction deposits upwards), which shows that it is not a matter of remobilised, but parautochthonous material, which lies in the uppermost parts of the solifluction package. Somewhat problematic are the tundra gleys (12), (13) and (14), which were difficult, and partly even impossible to find during the inspection on the 8 April 1954, under the guidance of Mr. Freising - who is sincerely thanked here - and to which I do not attach any stratigraphic importance. A close parallel to the Austrian profiles would be that the lower solifluction deposits (16) and (17) have a strong colour intensity, while the upper ones are less pronounced in this respect (i.e., in chroma) but not in their darkness (i.e., in value). This translates to the fact that the lower solifluction deposits really represent the erosion of interglacial soils, whereas the post-interglacial solifluction deposits are often composed of newly formed soils that have been solifluidically displaced and only rarely originate from the interglacial soils themselves.

The clay pit in Lauffen at the River Neckar, which was studied on the same day, again completely confirmed the recording of Freising (1953). In spite of large colluvial displacements - especially at the eastern wall - it is, however, striking that the position of loamy zone material to humus zone material ("subsoil" to "topsoil", which, however, is incorrect, because here, too, two periods of formation have generated two soils) is never inverse. Thus, the displacements have a more par-autochthonous character, even here, where the colluvial nature becomes very obvious. Thus, these two formations - the soil of the interglacial and the product of the commencing glacial - gain stratigraphic value and are to be equated - also conceptually - with the really autochthonous soils of the Austrian (and East Central European) dry area.

The discussion about the profiles from Bavaria made known by Brunnacker (1953, 1954a, b, 1955a, b) would require significant space. However, these are known to the author only from the literature, and therefore it is not permissible to go into detail. Here a general remark can be made that for palaeopedology the same difficulty exists as for the entire soil science: The communication of our observations is very difficult, since the description of soil profiles has not yet been standardised. In Europe, only recently and thanks to the decade-long experience of soil mapping in the USA, a more exact and widely understandable system of recording has been used (e.g., by using the American colour charts for the description of the soil colour, designations for structures, and, of course, also an increased integration of chemical and physical investigations). However, there still remains - due to the subjective nature of studying a soil profile - a margin of how to approach the issue, which makes decisions based purely on the literature problematic. In the present case, however, some observations seem to me fully sufficient so that parallels may be drawn, others, however, not yet, as for example the "brown weathering horizon", to which a substantial stratigraphic importance may be attached.

Again, it should be pointed out that the regional soil differentiation presented by Brunnacker (1955b), and specifically his coordination, became known to me only at the conference in Lauffen, where I presented the idealised profiles for the humid and dry loess landscape of Austria, shown in Fig. 5. From our close agreement on the issue it becomes obvious how far we have already come by exact field observations and how much palaeopedology has helped us on the way to a relative chronology. It is self-evident that as a second step this science could also provide exact information about past biotopes (based on comparisons with modern soils) and thus build a bridge to palaeobiology and other disciplines. 


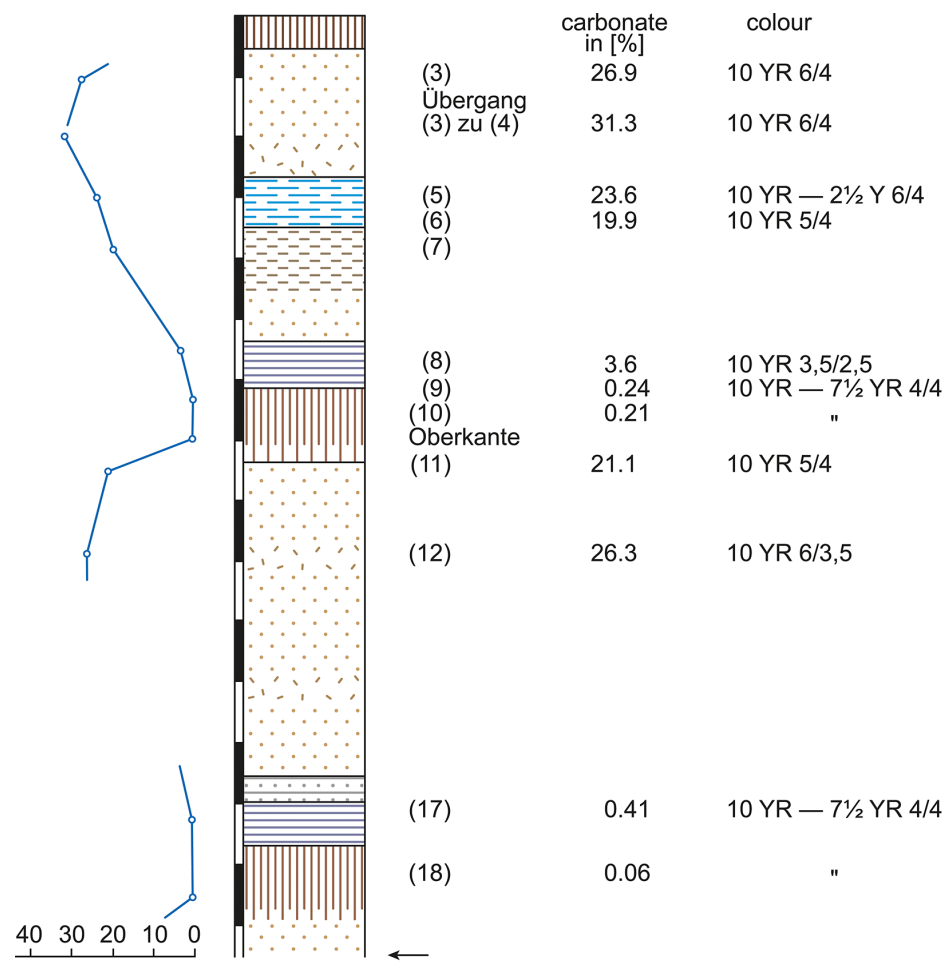

Figure 6. Profile Böckingen near Heilbronn.

Brunnacker (1955b) also concluded that today's annual precipitation can be used without further problems to characterise glacial climatic conditions, even if there are certainly minor overlaps in marginal areas (comparable to our "transitional area", where the interglacial is oriented towards the dry, and the beginning of the glacial towards the humid loess landscape).

Brunnacker (1955b) distinguishes seven sections from $\mathrm{N}$ to $\mathrm{S}$ in the (West)Central European periglacial landscape, namely:

1. loess-free area,

2. unstructured loess on top of solifluction deposits or stone pavements,

3. loess with tundra gley, solifluction deposits underneath (from the Rhine-Main area over $600 \mathrm{~mm}$ present annual precipitation),

4. like (3), only instead of the gley a "brown weathering horizon" (dry area of Main-Franconia),

5. with brown weathering horizon, but then between loess and solifluction deposits (probably) another brown weathering horizon (northern facies district of Brunnacker (1954b),

6. same as (5), only gleyic soils take the place of the brown weathering horizons (middle facies district of Brunnacker, 1954b),
7. cover loam (in German: "Decklehm"); closer subdivision due to glacial displacements not ascertainable.

By comparing this to the brown weathering horizon of the dry area of Main-Franconia, one immediately notices possibilities of drawing parallels here, just as the (upper) tundra gley probably corresponds to that of our humid loess landscape. The division into the lower brown weathering horizon (5) and the (lower) tundra gley (6) has not - or not yet? - been confirmed. However, it must not be forgotten that the emphasis of our loess research focussed for a long time on the dry area, where also most outcrops are found. But I would like to draw attention to the sequences in the East-Central European area, although we cannot yet show a correlated classification with (5) and (6). As will be explained further below, it seems to me to be a regularity that towards the east a far greater subdivision occurs in the loess profiles, which becomes more and more indistinct towards the west with an increased humid influence. On the other hand, such a division would have to start from southern Bavaria towards the dry area of MainFranconia, where, on the other hand, a "depletion" can be observed. Since the Austrian area (cf. Fig. 5) can be correlated with the sections (3) and (4) rather than with the sections (5) and (6), the latter area remains somewhat isolated.

Better known to me, thanks to the friendly guidance by my colleague Schönhals, to whom I would like to express my special thanks at this point, are the Hessian loess profiles. Schönhals (1950, 1951a, b, 1952) himself has reported on them in detail. Figure 7 attempts a short summary, whereby I 
would like to emphasise typological rather than stratigraphic points.

To the profiles in detail:

1. Hollow way between Erbach and Eichbach, described by Schönhals (1950) and Freising (1954). On the ascent to the upper middle terrace the path shows on the left and on the right several, partly collapsed outcrops, from which it can generally be read that there is a thickening of the loess and soils towards the valley, since the path lies in a depression which itself led to a thickening of the layers, but also their partial disturbance. Thus, the upper loess contains repeatedly gravel stringers (marked on Fig. 7/1 as alluvial loess), and also the fossil soil complex shows traces of a rearrangement. Similarly, the band of volcanic ash, so characteristic for most of the Rheingau, is not present, so that even the uppermost parts of the top loess are unlikely to represent a complete succession (visited on 6 May 1955). From three small exposures along the hollow way, the uppermost of which (a) is located near the "edge" of the upper middle terrace, (b) and (c) close together, to the left and right of the road (and corresponding to the point $145 \mathrm{~m}$ above sea level shown by Schönhals (1950) in Fig. 2), the following thickening against the valley could be established:

\begin{tabular}{lll}
\hline (a) & (b) & (c) \\
modern soil & as with (a) & as with (a) \\
loess & loess with grav- & loess with grav- \\
"tundra gley"? & els & els \\
loam zone & "tundra gley" & "tundra gley" \\
calcareous & some loess & immediately \\
enrichment & mottled horizon & below crotovina, \\
horizon & humus zone & filled with grey \\
Tegel & loam zone & sand \\
& calcareous & light grey loess \\
& enrichment & humus zone \\
& horizon &
\end{tabular}

Based on personal communication with E. Schönhals, a $10 \mathrm{~cm}$ wide light-coloured (loess?) stripe was observed between the humus zone and the loam zone at a location close to (b) and (c).

Through the above-mentioned disturbances, it seems that a discrepancy with regard to field observations has arisen (see Fig. 2 in Schönhals, 1950 with Freising, 1954 profile 4 of the Appendix). Nevertheless, I believe that an interpretation is still possible and would classify the basal sequence still to belong to the Stillfried complex. The loamy zone with strong colouration (7.5YR 5/6) and a strongly calcareous enrichment horizon corresponds completely with the Austrian conditions. This is overlain by the humus zone - or even with an intermediate layer, see above - whereby the colour value of the humus zone 10YR 4/2.5, the still preserved loess structure and the following mottled horizon above (consisting of lumps of loess zone and humus zone material, approx. $5 \mathrm{~cm} \varnothing$ ) are well known from the often weakly solifluidally influenced profiles of the Austrian dry area. The loess layer above is disturbed by gravel layers and sand bands; nevertheless, the grey zone lying at about $0.5 \mathrm{~m}$ above the Stillfried complex could be identified as a tundra gley. The crotovina in it provide again evidence for a likely parautochthonous character of the strata lying above the complex (see profile Böckingen near Heilbronn).

(No final judgment can be given about the exposed section at the brickyard Schlüter in Eltville, which was visited on the same day, because the outcrop had largely collapsed. However, the strong colours of the fossil soils of the Erbach hollow way were not present, so that the whole sequence of strata present there is likely to be younger).

2. Brickyard in the $\mathrm{W}$ of Bad Homburg (as the following profiles visited on 7 May 1955 under the guidance of Schönhals), probably situated on the main terrace. Figure $7 / 2$.

Here, in the lowest part of the modern soil (belonging to the Lessive group) the grey ash band is located, the tundra gley is clearly formed, under which follows a layer of loess dolls. The package here very clearly is named "Linzer complex" in Austrian profiles: the autochthonous soil with medium blocky structure, the coatings on the aggregates and at its upper limit the laminated, grey, weakly gleyed solifluction deposits, which also contains charcoal pieces. A slight gley-like overprinting of the overlying subsoil from above, recognisable by isolated patches of $\mathrm{Mn}$, is also fully consistent with the picture of the humid loess landscape of Austria. The loesses below the Linz complex are strongly gleyed, loess dolls layers are present, and a subdivision does not seem possible.

The profiles described under (1) and (2) are $30 \mathrm{~km}$ apart. Since both are typical for special climatic areas, the border of humid and dry loess landscape must have been between them.

3. Berstadt, natural outcrop at the entrance to the town on the left of the road. (Its exact description may have in the meantime been given by Schönhals).

The modern soil here is a "dark brown steppe soil", which I have not yet observed in the Austrian dry area. It seems to be typical for larger areas of the Wetterau and could also be observed in an outcrop near Wilfersheim. Below this, the volcanic ash band soon follows, but very soon a wedge of redeposited soil material thickens towards the road (where the outcrop height increases), which again lies unconformably on the solifluction deposit, which covers the autochthonous soil 


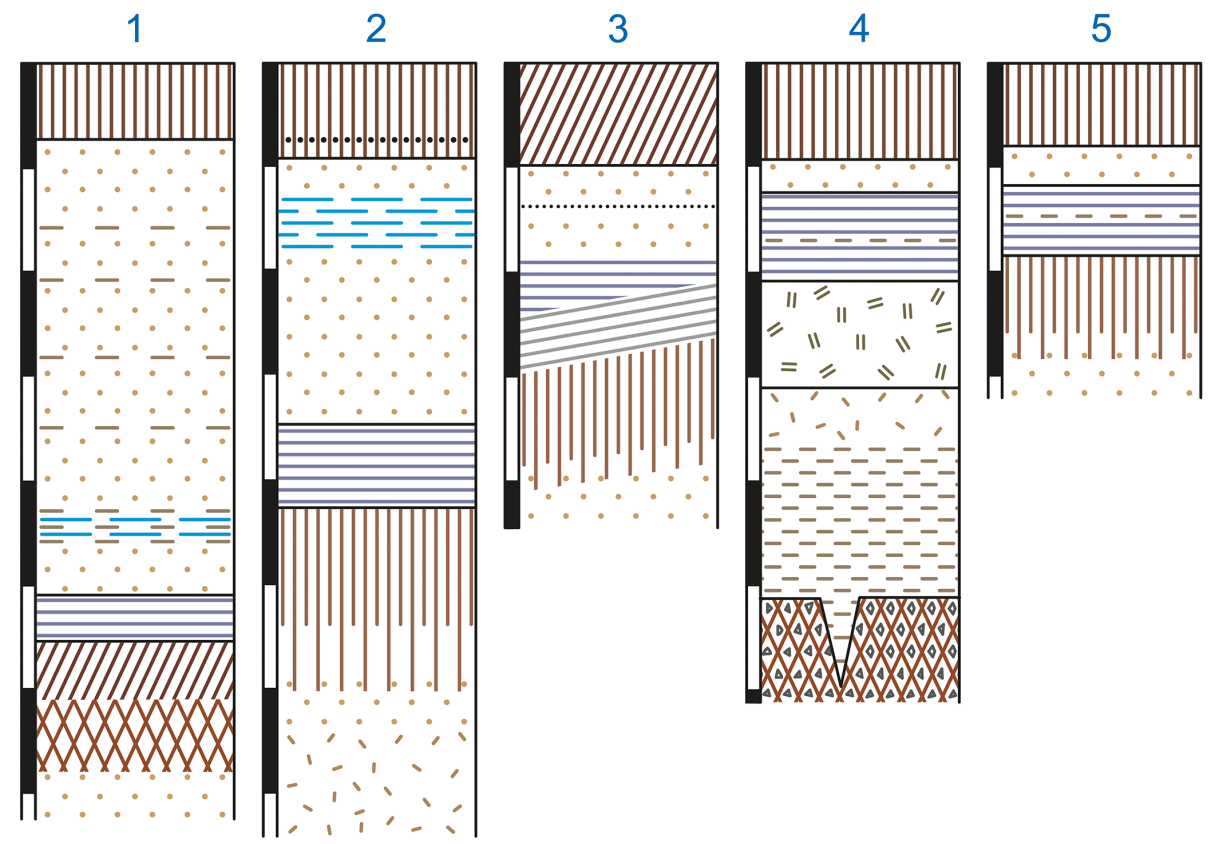

Figure 7. Hessian loess profiles; from left to right: (1) Hollow way between Erbadi and Eichbach, (2) Bad Homburg, (3) Berstadt, (4) Laubach, and (5) Queckborn.

and dips towards the road maintaining a constant thickness (see Fig. 7/3, where the two solifluction soil packages are schematically drawn). Both, the lower and the upper solifluction deposits have more the character of the often remobilised soils of our "transitional area" than that of the distinctly humid loess landscape. The autochthonous soil is also more intensely coloured than that of Bad Homburg, however, it does not reach the red colouration and the habitus of our equivalent formations from the transition area.

Nevertheless, a certain special position - towards the "dry" side - must be attributed to the recent as well as to the fossil soil, which would also correspond well with today's climatic conditions. It is therefore understandable that also the gleyification in this profile recedes strongly, but this cannot be attributed solely to the relief of the fossil landscape.

4. Brickyard Laubach, described in detail by Schönhals (1951a). In his Fig. 5 a general overview is given. The general decrease of loess thickness towards the Vogelsberg already brings a shortening of the profile, yet it still reaches back quite far in time as shown by the basal basalt debris (with soil) which is interspersed with ice wedges.

Below the modern soil (Lessivé group) follows a very thin layer of loess. This is underlain by a package of solifluidal material showing a laminated structure, slightly gleyed, under which a much more gleyic package of solifluction deposits follows (the step is marked by a thin layer of alluvial loess on Fig. 7/4). Also, the soil in place is gleyed and passes towards the bottom into the loess loam interspersed with local debris, and then stratified loess loam.

When interpreting the profile, the separation between the pseudogley and the overlying solifluction package is particularly important, because this contact separates the (albeit overprinted) interglacial soil from the incipient glacial solifluction deposits. However, a crotovina from the "remobilised" layer indicates again the parautochthonous character of the profile (cf. above).

5. Queckborn. A small, largely collapsed outcrop west of the village offers a roughly similar situation as (4) and is shown in Fig. 7/5. Below the modern soil (Lessivé group) follows loess, below it again an "upper" package of redeposited soil material, below it the actual greyish, strongly gleyed solifluction deposit package, which rests on the autochthonous soil. This is only slightly gleyed and very similar to the Bad Homburg soil. Again, the boundary between the preserved subsoil of the interglacial and the solifluction deposits is clear, the upper package, however, as in (3) and (4), is separated. Whether a stratigraphic value of its own can be attributed to it (perhaps as a substitute for the tundra gley) cannot be determined from such few outcrops.

This catena through the Hessian loess landscape should actually be extended by another profile which represents an end member with respect to the gradual thinning of the loess cover and thus of the fossil soils: At 
Beltershain, the subsoil of the Linz complex is already part of the present-day soil (the fossil soil thus became a relict soil). $3 \mathrm{~mm}$ thick, chocolate-brown clay-irons are deposited in fissures and crevices (completely identical to the forms recorded in Fig. 1 by Schönhals, 1952), the thickness of which is characteristic for only fossil, but not the modern soils of the Lessivé group.

Therefore, we are not wrong if we divide the Hessian area, at least for the period of the Stillfried and Linz complexes, into several climatic zones similar to the Austrian loess landscape.

But also, considerably further in the $\mathrm{W}$, in Belgium, the sequence characteristic for the Central European area (Linz or Stillfried complex) can be found again. The loess profile of Rocourt (suburb of Liège), which was described by Gullentops (1954), could be visited under the guidance of Dr. Dudal on 1 May 1955. Figure 8 presents a schematic drawing of the profile, with the numbers in brackets referring to the zones defined by Gullentops (1954, p. 145 ff.).

Below the modern soil follows a loess, which rests on a strongly cryoturbated tundra gley. Under this "tongue shaped zone", which Gullentops (1954) found in several profiles of the Hesbaye area, the profile in Kesselt are especially instructive (and which therefore are of stratigraphic value), follows a gleyed, already weakly stratified loess, which gradually changes into typical solifluction deposit with a distinct lamination. This solifluction deposit, clearly humous in colour, becomes parautochthonous in the lower layers, which shows strong earthworm mixing. Below follows an intermediate zone with strong gley concretions, underlain from the upper part of the gley-like altered soil, which rests on a (thin) basal loess. The base is formed by Oligocene sand.

Again, there is - albeit strongly modified - a gley-like, overprinted soil on top of which follows a solifluction deposit package. The floor above is interrupted by a distinctive caesura (tongue shaped zone), above which gley and alluvial influences can no longer be observed. Thus, the same sequence as can be observed from the other areas. However, a final classification and evaluation of the Belgian profiles can only be made after the (North) French outcrops have been included.

Finally, only brief reference should be made to the relations between the dry loess landscape of Austria and the neighbouring areas to the north, south, east and south-east. The Bohemian, Moravian and Slovakian areas have in recent times become particularly well known through extensive work by Czech scientists. However, we will not go into this literature in detail here, because Brandtner (1956) will discuss the Czech works in detail in connection with his questions. In general, however, it can be stated that apart from the exemplary palaeontological and prehistoric recording of the individual localities, the morphological conditions have been given somewhat too little of a consideration. Moravia in particular would offer a unique opportunity to trace the terraces from their roots, to record them in chronological order and to correlate the loesses; it is to be hoped that this will be done in the future. A pedological evaluation, as carried out by individual researchers, could perhaps also be geared more towards the more recent findings obtained in neighbouring states. A number of very interesting, but in our opinion untenable, ideas concerning the periods of loess formation are widespread and thus also influence the pedological interpretation: Ambroz (1947), for example, came to the conclusion that "loess formation can only occur in the first half of the interglacial", while in the second half degradation is supposed to have set in due to the advance of the forest. Žebera (1953), on the other hand, took the view that "[...] the sedimentation of loess began in the second half or towards the end of the interglacial". Pelišek (1954) indicates eight loess deposits for (his) Rissian-Wuermian (= Saalian-Weichselian) interglacial alone! For "the loess deposits were formed here not only in the individual sections of the Rissian and Wuermian glacial, but also in the interstadials and interglacials. The existence of interglacial and interstadial loess is proven for our Pleistocene area".

Nevertheless, the excellently presented and widely studied observation material, together with that published by German authors (Lais, 1951; Schönhals, 1951b), permits the following general statement:

Bohemia and Moravia are characterised by loess sequences with a wealth of fossil soils that far exceeds the inventory of the Austrian loess landscape on average. Based on our objectives, only the uppermost fossil soil formations of these profiles are used for comparison. That zone, which all Czech authors refer to as W1/2, corresponds fully to the Stillfried Complex (the stratigraphic correlation is not under discussion here!). Musil and Valoch (1955) stated that between the second and third loess "there is always a black earth (sometimes also duplicated), which usually has a rusty brown B horizon" (regarding the "B horizon" see above and below). In the original work by Musil et al. (1955), the Stillfried complex is often represented in the numerous profiles in their Table III. Significantly, this complex preserves the uppermost occurrence of ice wedges (as far as they are filled with black earth). If ice wedges still occur in the overlying soil formation (cf. Schönhals, 1951b, Figs. 3 and 6), then these are filled with loess. The large loess landscape of Inner Bohemia and Moravia (the extent of which is very clear on the distribution map of Urbanek and Sýkoro, 1955) can thus be separated from the "normal" Lower Austrian landscape by the predominance of ice wedges. The border could roughly coincide with the Thaya. While the classical profile of Unterwisternitz (cf. Lais, 1952), which Brandtner (1956) discusses in greater details, corresponds fully to the profile of Stillfried (cf. Fink, 1954), the Brno area is already char- 
acterised by the occurrence of ice wedges. In Lower Austria these are absent, they are only found locally in specifically bedded (humid) sequences (e.g., Weinsteig, cf. Fink, 1954), but always only within the loess, not, as in Bohemia and Moravia, within fossil soils sequences. Very instructive are the photos by Lais (1951), which show a zone of loamy soil underlain by a horizon enriched by secondary lime precipitation and interspersed with ice wedges (filled with black earth) (Prague-Selz and Wischau). One would assume that such an observation is always interpreted correctly, as Büdel (1949) did during a presentation of a lecture by Schönhals: "[...] these profiles show clearly that the interglacial soil horizons became disturbed by frost cracks during the next glacial period". It was stated clearly here that the soils of the (last) interglacial must be sharply separated from those of the (beginning) glacial period. Nevertheless, in various works, humus and loam zones appear as A and B horizons of a soil, even if there is also an intermediate layer of loess (which can be observed very frequently in our arid region). Therefore, we cannot follow Schönhals (1951b), who describes "strongly podsolated soils". Numerous curves showing soil carbonate contents in the latest Czech works are in full agreement with those of Brandtner (1954) and Fink (1954) and provide evidence that not leaching but a new period of loess accumulation had occurred.

The "pale soil" of our dry area is also found in most Czech profiles; it therefore has stratigraphic significance. The classification of both the Stillfried complex and the lower-lying soil formation by the Czech authors is premature without a reliable terrace correlation.

The "strictly continental" ice wedge province (Bohemia and Moravia) is contrasted by the Slovakian area, which resembles the Lower Austrian loess landscape. The usual division of the profiles by fossil soils is not developed, the Stillfried complex is formed without modification (cf. e.g., Ambroz et al., 1952, description of the profile of Moravany in the Váh valley).

There is (as far as I know) little information available about the Silesian area. From the description of the conditions in the Glatzer area by Berger (1932) it can be learnt that there seems to be a sequence similar to the Linz complex, only much shorter. A clayey residual soil forms in the upper portion of an older loess (which in turn rests on till). On top of the residual soil lies a layer with "mostly broken snail shells" and with calcareous concretions, which transitions to a calcareous (younger) loess; above this follows the modern soil. The layer sitting on top of the residual soil can only be interpreted as a solifluction deposit.

A certain change (compared to the Austrian situation) seems to be taking place in the Hungarian area and in the Yugoslavian area. Again, sequences with a large number of intercalated soils are available. For the time being, they do not seem to be easily comparable to the Czech and Austrian forms - not only because of the rather schematic representation and brief description. Of central importance for the
Hungarian region is the classic profile of Paks, which was recently presented in a monograph by Krivan (1955) at the III. INQUA Congress. For the first time, Scherf (1936) had reported in detail about this profile, because it was a pivotal record for the polyglacialist conception (which at that time was only gradually gaining acceptance in Hungary). Bacsak (1942) found his new classification, which was based on Milankovic's radiation curve, confirmed in the field surveys (which were carried out together with Scherf); in the meantime, Bulla (1938) had summarised both the terrace and loess stratigraphy of the Hungarian region and also described the Paks profile.

The work of Krivan $(1955)^{3}$ is divided into two sections: The first deals with the climatic structure of the Pleistocene in Central Europe; his Table 1 summarises the results. This section, which is based on the calculations of Bacsak (see above), cannot be discussed in detail here. The second is devoted to the profile itself, the pedological, granulometric and palaeontological record is very clearly presented in an overall profile in his Table 3. This has the advantage of fully reflecting the actual sequence, whereas his Table 1 attempts to give a theoretical and complete division of the Pleistocene. As in the discussion of the Czech literature, the stratigraphic division is not discussed here (Riss is divided into two, Wuerm into three, W1 is called Warta, etc.), because it is already clear from his Table 2 how much the opinions of the latest editors of this profile (six after 1945) diverge on this question.

The differentiation of the upper part of the profile, which is important to our question, is very limited. The first interruption of the uppermost loess is represented by two (barely) soil formations between 9.5 and $12.5 \mathrm{~m}$ depth, separated by an intermediate loess layer. The loess above is said to have no structure; however, in a photograph kindly provided to me by Prof. Dr. Rungaldier, taken on 19 September 1930, I believe I can recognise a pale soil above the two adjacent soils (typologically they are not well defined) in the uppermost third of the upper loess. Unfortunately, in the photograph by Bacasak (1942), which is still the clearest of all the pictures published so far, the uppermost part of the youngest loess is not depicted, so that no comparison can be made.

It is very important that Bacsak (1942) emphasises the regional significance of the profile in Paks: "This is a profile that can be followed along the Danube further to the south within the same formation. In Vukovar, I saw the laime zones on the banks of the Danube, on the steep walls of the hollow ways of the old town and in outcrops at the local brickyards showing exactly the same sequence of strata as described in Paks". Based on the literature alone, we may doubt a coincidence of the overall profiles (Paks and Yugoslavian area). The Quaternary strata in Paks are almost $50 \mathrm{~m}$ thick, while the Danube terrace on the right bank between Vukovar and the northern slope of Fruska Gora is on average $30 \mathrm{~m}$ above

\footnotetext{
${ }^{3}$ Presented bilingually in Hungarian and French.
} 
the Danube level, but the base thickness under the (jointed) loess must still be subtracted (cf. Markowic, 1954, Fig. 1).

Particularly from the Yugoslavian area, very valuable observations have been made with relevance to our field questions. Markowic (1951a) was able to prove, on the one hand, that the loess distribution extends far beyond the southern edge of the Pannonian basin into the area of Niš, with several loess islands in the valleys of the Morava (Markowic, $1952 \mathrm{a}, \mathrm{b})$; in most loess outcrops a differentiation is possible based on the intercalated soils. On the other hand, we owe to this researcher a new survey and addition of previously known spaces, such as the loess plateau of Titel and the northern and eastern slopes of Fruska Gora (Markowic, 1951b, 1954), building on the stratigraphic summary of Lascarev (1951). The papers emphasise that the basal layers of the loess profiles (in the Danube area) comprise marsh sediments that correspond to the end of the Great Interglacial. If this age classification is correct, then it would prevent a correlation with Paks (which would also not be possible for other reasons given above) forcing us to classify the many soils present here (individual profiles have up to eight fossil soils). However, this is not yet possible based on previous, non-typological descriptions; but it will certainly be possible to distinguish this area as a separate "facies district", based already on the large distance from the Nordic and Alpine ice bodies. This distance also explains the greater number of fossil soils, i.e., similar effects caused be fluctuations in conditions are not to be expected to appear over smaller distances, and if so, then not yet as fully developed soils. There is a consistency that emerges from the examination of the stratigraphic value presented by fossil soils, which - as will be shown below - is valid in the opposite manner for the division of the terraces.

It has already been pointed out several times that the loess stratigraphy can only become definitive once a robust correlation with the terraces has been established. The Austrian region, especially the northern slope of the Alps, also offers important records for this. It must be emphasised, however, that for the second question dealt with in the present work there is far less observational material available. This is due to the nature of the subject matter: Here it is no longer sufficient to make a point-by-point survey as was done in the case of the loess profiles; here entire areas have to be looked at. However, these are not yet known from all parts of the northern slope. As the older literature can only be used to a limited extent due to inadequate descriptions (mostly only morphological information, without recording the sedimentary and soil content of the terraces), only the results of the most recently studied areas are useful. These are the Salzburg-Upper Austria area on the one hand, and the (wider) Vienna area (Tullner Feld, Marchfeld, south-eastern Vienna Basin, northern Burgenland) on the other. In between, however, there are well-structured terrace systems on the tributaries of the Danube and between the Enns and the Vienna Woods (Ybbs, Erlauf, Pielach, Traisen, Perschling and Tulln), which are still being studied. The Danube itself cannot establish the connection, because in the breakthrough sections through the Bohemian Massif (Strudengau and Wachau) no terraces have been preserved for the most part. Therefore, further research in this section of the northern slope will have to be limited to separate recordings of the tributaries.

However, the tracing of terraces from their origin (moraines) to the extensive gravel plains of the Vienna area would not be possible even without the (terrace-free) valley sections of the Danube. This is because the imbalance of the ice proximal areas will always mean that they behave differently than the periglacially influenced distal gravel plains.

For the area near to the glacier, principles that Troll (1926) had already worked out 30 years ago apply. There, a continuous Low-Terrace is not found, instead it is divided into several subordinate surfaces, cf. the terrace map Vöcklabruck - Enns (Table III of the excursion guide 1955). Admittedly, the lower terrace dominates over long stretches, which thus could be called the "main field". In contrast, the HighTerrace, which is clearly distinguished from the Low-Terrace by its loess cover and its numerous minor depressions, has no such subdivision.

The individual smaller areas of the lower terrace are always of local importance. For example, the two lower terraces in the Salzach end moraine area mapped by Weinberger (1955, Table II), which originate from two different young moraine arcs, and later join after a short distance in the Weilharter and Lachforst to form one large field; the intermediate terrace occurring in the same area, interpositioned between the High- and Low-Terraces (in this case the main field), is only locally present. The situation is similar with the glacier terraces mapped by Prey (1955, Table III). Despite the predominance of the main terrace, the Traun shows how the confluence of side channels (near Lambach, near Wels) causes a proliferation of smaller terraces, some of which merge into each other and thus remain without stratigraphic value. According to Schaderler (cf. Kohl, 1955), the subfields do not have their own Tegelian base but have merely been erosively levelled.

The number of minor terrace surfaces below the (connected) High-Terrace is so large because several Holocene surfaces also occur. Götzinger (map sheet Mattighofen) has defined a series of Holocene subfields on the Inn, and such surfaces can also be observed on the Traun. With the help of pedological criteria they can be separated from the Pleistocene ones, as the soils developed in them represent far more immature types (cf. Janik's contribution in Kohl, 1955). Furthermore, the Holocene forms are characterised by the absence of any frost phenomena. Although the area close to the glacier is characterised by only extremely weak cryoturbations - in contrast to the area far from the glacier where intense frost structures occur in terraces and surface layers cryoturbations of a smaller extent have also been found here recently. These were, of course, limited to the Pleistocene forms, while it must be emphasised that the last frost action 


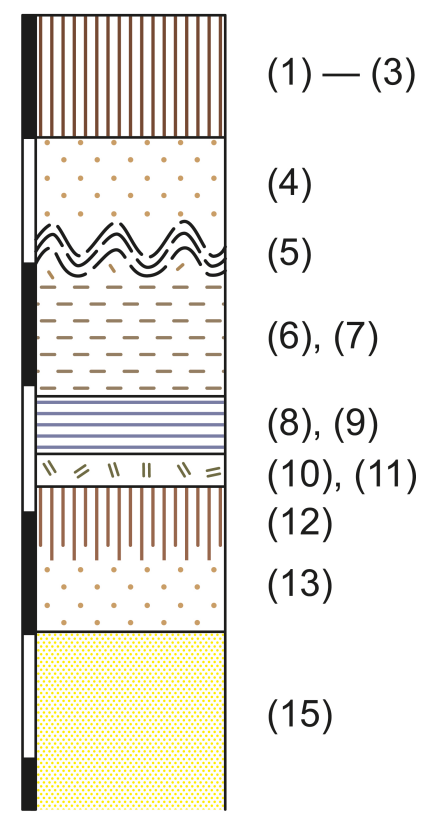

Figure 8. Profile of Rocourt near Liège.

must be placed in the Younger Dryas (= final glaciation of Ampferer). Similar observations are now also known from many places in Austria which go back to periglacial influences after the melting of the Wuermian glaciers: Independently of each other, Weinberger (1954) found ice wedges on Wuerm moraines near Brunn and Verf at the edge of Lake Heratinger, only a few km away, as well as in Thalgau in several gravel pits on the same deposits, while in Waidring and north of Kirchdorf (Tyrol) even continuous cryoturbations were discovered. (In the latter case, this was exposed in a freshly excavated trench over a length of $200 \mathrm{~m}$ ). I also know of (smaller) cryoturbations from the ground moraine landscape of the Drau Glacier. All these observations, which for the time being are located far apart, will increase in the course of time and provide evidence that at the time of the Younger Dryas the whole of Austria once again came under the influence of a periglacial climate.

Nowhere on the surfaces of the lower terrace occurred the pitting by small surface depressions. The latter is only to be found on the High-Terrace, which is heavily overlain in each case, with the most pronounced forms occurring in the area of the Inn (cf. Weinberger, 1954), whereas on the Traun and on the Danube (Linz area) only trough forms are present. Connected or branched forms have not been documented. The dissection, which is associated with the morphological division of the plains by the development of gullies and small valleys, is characteristic of the upper sheet gravels. This results in an idealised summary profile for the area close to the glacier, as shown in Fig. 9. (Kohl, 1955, Table III, has separated out terraces in the Aiterbach valley, which join the Traun near Wels; in the city area of Linz and near Enns, which perhaps represents a certain intermediate position between High-Terrace and sheet gravels in general. They were assigned to the sheet gravels in his Table III and are thus not included in the schematic profile in Fig. 9). The arrows indicate significant breaks in development. One of these is placed between the most intensely dissolved sheet gravels and the High-Terrace, the second between the latter and the subfields of the low terrace. A thin arrow marks the boundary to the Holocene.

It is natural that this nomenclature should be used for the area close to the glacier, from which most of the classic research started and from which the terminology that is now valid worldwide was originally derived (especially since it is perfectly adequate for our area). However, it poses difficulties to apply this nomenclature for the glacier-distal areas of the northern Alps. In accordance with a suggestion by Woldstedt (1953), it will be more appropriate at the present stage of our fieldwork to work with local names, which can at a later stage be transferred into a broad system.

The (wider) Vienna area has been the subject of intensive research over recent years, with problems being approached from different angles. Firstly, based on a new geological survey (Grill, Küpper, map of Vienna, map of Gänserndorf) aided by new hydrogeological (Küpper) and palaeontological (Papp and Thenius) findings and finally new results from geomorphology and soil science (Fink and Majdan) ${ }^{4}$. The old technique of recording morphological form alone had long since given way to a far broader inclusion of more observational factors. Particular attention was given to the tectonic situation of the Vienna Basin, as even the most recent subsidence still reaches large amounts (see below); for these interpretations a large volume of drilling data is available. Despite the instability in the inner parts of the basin, it is striking that the overall basin framework has remained rigid, so that terraces cut into or overlying it can be correlated over long distances. It seems that in the area close to the glacier, the influence of tectonics (mainly because of the longitudinal direction of the main valleys and their relatively minor width) is somewhat less intensely felt, than is the case for the larger river plains which strike perpendicular to the mountain front in the east.

Already in the Tullner Field, but especially in the March Field, tectonic subsidence of greatest extent is noticeable, which has shifted the base of the lowest terrace (=Prater Terrace) from an average of $-10 \mathrm{~m}$ in the narrower Vienna area (near the breakthrough through the Vienna Gate) to more than $100 \mathrm{~m}$ (cf. map of the Tertiary underground of the March Field by R. Grill, presented on the DEUQUA excursion, 1955). In the southern Vienna Basin, too, the guidelines described by Stini (1932) have now been precisely recorded by Küpper (groundwater map of the southern Vienna Basin, presented on the DEUQUA excursion in 1955) and show

\footnotetext{
${ }^{4}$ Literature references are not given here; please refer to Fink and Majdan (1954) and Fink (1955a).
} 

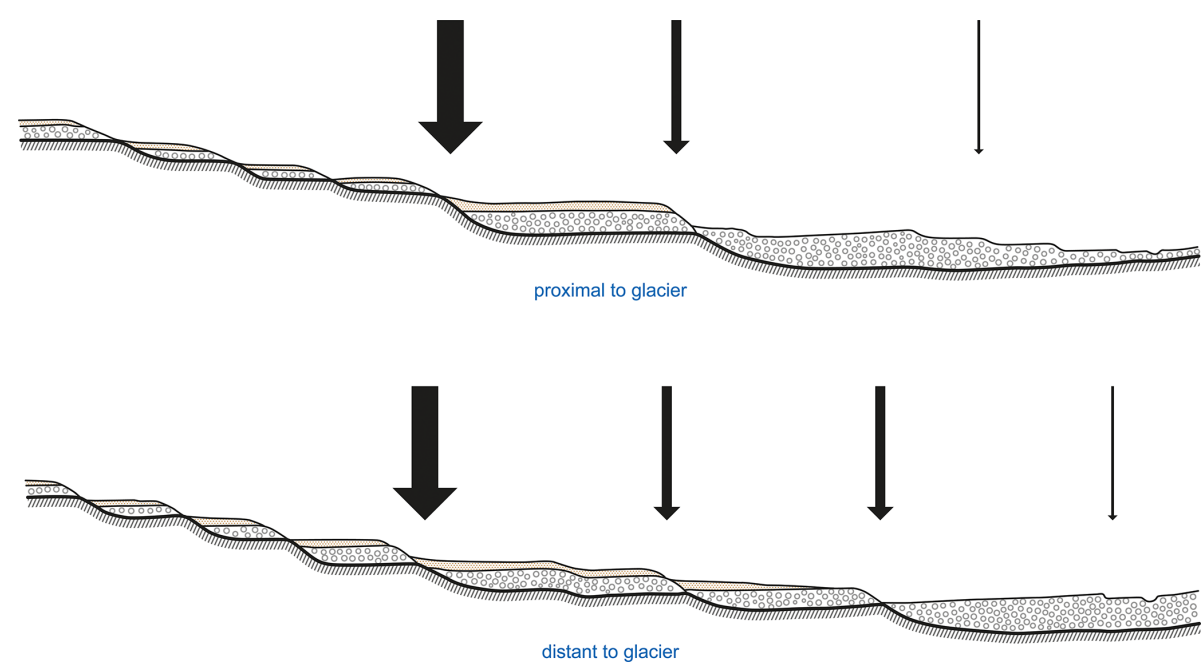

Figure 9. Terrace system diagram for the northern portion of the Austrian Alps.

high subsidence amounts. However, these movements must also have had great effects in the large Hungarian basin landscapes, so that the Vienna area forms a bridge to the southeastern European landscapes.

The terrace model given by Fink and Majdan (1954, profile 6) for the (narrower) Vienna area remains unaffected by this, as the subsidence only reaches its maximum in the longitudinal axis of the basin. It therefore coincides with the terrace scheme for the area far from the glacier (Fig. 9). After further fieldwork has been carried out in the southern Vienna Basin and Tullner Field, it can be considered valid for these partial landscapes as well. (An inclusion of the adjacent Hungarian and Czech areas cannot be ventured on the basis of the literature alone. However, some very good photographs by Prof. Rungaldier show that typologically similar terraces (as in the Vienna area) also accompany the Danube in the large basin landscapes).

One more general observation should be made: Winkler von Hermaden (1955) in his latest, extensive work, which mainly concerns the south-eastern ridge, has placed the emphasis on the presence of interglacial terraces. For the Vienna area, the accumulation of gravel bodies occurred uniformly during cold periods.

In contrast to the areas near the glacier, there are now three important phases distinguished. The second youngest terrace ( $3=$ Gänserndorfer Terrace) has been newly added, as one may safely say, as a dominant element. Its petrographic, morphological and pedological differences compared to the Prater Terrace were demonstrated in detail during last year's DEUQUA excursion in the March Field (compare Fink, 1955a) and were probably also recognised by all participants: The Gänserndorf terrace is characterised by its own Tertiary base, which lies only slightly below the upper edge of the Prater Terrace, furthermore it features pronounced cryoturbation and a specific cover sediment (old drift sands, which, however, are also found on higher terraces between the Danube and Lake Neusiedl). The margin of the Gänserndorfer Terrace shows numerous small depressions, which reach far back into the terrace, but always remain nonbranched.

A large break in time separates the Prater Terrace from the Gänserndorf Terrace, but a similar lapse separates the latter from the terraces above. In Fig. 9 we assume two merging terraces above the Gänserndorfer Terrace, which correspond to the two terraces west of Seyring (Grill, Geol. Map of Gänserndorf). For the time being, a more appropriate local name has not yet been found, although these terraces (sometimes merged into one) are widespread. After consultation with my colleague Majdan, Fink (1955b) therefore put forward another name for discussion:

\section{- Prater Terrace}

- Gänserndorfer Terrace (local modifications: Stadt Terrace, Mannswörther Terrace, Simmeringer Terrace in the vicinity of the central cemetery).

- Middle Terraces (higher and lower terrace west of Seyring, Simmering Terrace outside the abovementioned area)

- Early Pleistocene terraces in general (Arsenal, Wienerberg, Höbersdorfer, Laaerberg terraces, etc.).

We were aware that the term "Middle-Terrace" already indicates a stratigraphic definition. Independent of this, the naming is also inconsistent, since the first two carry local names, while higher-level stratigraphic names follow later. But this was done on purpose, because the Great Interglacial is unlikely to undergo any further shift in time placement due to the new work in the Vienna area. However, the subsequent terraces must then inevitably take the position given above. 
But this is not about a naming problem! Rather, it is about the fact that three morphologically distinct caesuras recorded for the glacier-distal areas are contrasted by the classical system of only two! This question, however, can only be securely answered when the geology of the intervening space has been newly mapped. However, one thing has already become apparent: The required temporal division cannot be derived from the moraines or the immediately adjoining areas, but only from those areas in which continuous, individual, large gravel bodies can delineate the climatic rhythm of the Pleistocene, comprising the glacial and periglacial influence.

In the case of a correlation to the loess sequences the focus is on evaluating only the last of the caesura, or the subdivision of the lower terrace in the area close to the glacier (interestingly, the Prater Terrace shows no differentiation). When comparing the standard profiles of the humid and dry loess landscapes (Fig. 5b and c) with the terrace patterns of both areas, which roughly coincide in terms of distribution, the last clearly developed soil (Linz and Stillfried complexes) can only coincide with the break between the Prater and Gänserndorf terraces; in the humid loess landscape the connection is provided by those profiles directly on the HighTerrace (cf. Fig. 5a). The large solifluction packages of the Linz complex and the humus zones of the Stillfried complex coincide with the last major morphological transformation of the landscape, with the degradation of the High-Terrace and with the reworking of the old moraines, as already established by Büdel (1950, 1953). To assign the tundra gley into the arrangement of the lower terrace subfields would be just as futile to attribute a morphological expression to the pale soil of the dry area. These two formations, probably identical in time, were really only minor oscillations, by contrast the two soil complexes require a far longer interglacial time to develop followed by a typical early-glacial overprinting, which also must have had a significant effect on the morphology of the terraces.

There are two tasks that have to be solved in the near future: To find profiles that illuminate the normal sequence of the dry loess landscape on the Gänserndorf Terrace, and to map the terrace systems on the aforementioned tributaries of the Danube (some of which are autochthonous channels), on which or in which the change from the near-glacial to the far-glacial type is documented. The first task seems imminent, as it only requires the (terraced) insertion of an outcrop already found (for which the conditions apply) into a larger landscape area. For the second case, much field work is still necessary, so that it is advisable to be cautious for the time being in applying stratigraphic designations for our area.

Review statement. This paper was edited by Christine Thiel.
References

Ambroz, V.: The Loess of the Hill Countries, Ber. geol. Staatsanstalt der tschech. Rep., 14, Prag, 1947.

Ambroz, V., Ložek, V., and Prošek, F.: Mladý pleistocén v okolí Moravan u Piestan nad Váhom, Anthropozoikum, 1, 53-142, 1952.

Bacsak, G. V.: Die Wirkungen der skandinavischen Vereisung auf der Periglazialzone, Institut für Meteorologie and Erdmagnetismus, Neue Serie 13, Budapest, 86 pp., 1942.

Berger, F.: Zur Gliederung des schlesischen Lösses, Centralblatt für Mineralogie, Geologie und Paläontologie, 2, 1932.

Brandtner, F.: Jungpleistozäner Löß und fossile Böden in Niederösterreich, E\&G Quaternary Sci. J., 4/5, 49-82, https://doi.org/10.3285/eg.04-5.1.06, 1954.

Brandtner, F.: Lößstratigraphie und paläolithische Kulturabfolge in Niederösterreich und den angrenzenden Gebieten (Zugleich ein Beitrag zur Frage der Würmgliederung), E\&G Quaternary Sci. J., 7, 127-175, https://doi.org/10.3285/eg.07.1.13, 1956.

Brunnacker, K.: Der würmeiszeitliche Löß in Südbayern, Geologica Bavarica, 19, 258-265, 1953.

Brunnacker, K.: Über fossile gleyartige Böden im Löß Bayerns, Zeitschrift für Pflanzenernährung, Düngung, Bodenkunde, 65, https://doi.org/10.1002/jpln.19540650110, 1954a.

Brunnacker, K.: Löß und diluviale Bodenbildungen in Südbayern, E\&G Quaternary Sci. J., 4/5, 83-86, https://doi.org/10.3285/eg.04-5.1.07, 1954b.

Brunnacker, K.: Würmeiszeitlicher Löß und fossile Böden in Mainfranken, Geologica Bavarica, 25, 22-38, 1955a.

Brunnacker, K.: Die regionale Bodendifferenzierung während der Würmeiszeit in Mitteleuropa, Vortrag, gehalten auf der DEUQUA-Tagung 1955 - hektographierter Referatsauszug, 1955b.

Brunnacker, K.: Regionale Bodendifferenzierungen während der Würmeiszeit, E\&G Quaternary Sci. J., 7, 43-48, https://doi.org/10.3285/eg.07.1.06, 1956.

Büdel, J.: Neue Wege in der Eiszeitforschung, Erdkunde, 3, 82-96, https://doi.org /10.3112/erdkunde.1949.02.03, 1949.

Büdel, J.: Die Klimaphasen der Würmeiszeit, Naturwissenschaften, 37, 438-449, https://doi.org/10.1007/BF00638074, 1950.

Büdel, J.: Die "periglazial"-morphologischen Wirkungen des Eiszeitklimas auf der ganzen Erde, Erdkunde, 7, 249-266, 1953.

Bulla, B.: Der pleistozäne Löß im Karpathenbecken, Földtani Közlöny, 68, 33-52, 1938.

Dudal, R.: Etude morphologique et génétique d'une séquence de sols sur limon loessique, Agricultura, 1, 119-163, 1953.

Fink, J.: Prinzipielle Fragen bei der Erforschung fossiler Böden im österreichischen Löß, Verhandlungen IV INQUA Kongress, Rom-Pisa, 1953.

Fink, J.: Die fossilen Böden im österreichischen Löß, Quartär, 6, 85-108, 1954.

Fink, J.: Wegbeschreibung: Wien-Marchfeld-Stillfried, Verhandlungen der Geologischen Bundesanstalt Wien, Sonderheft D, Beiträge zur Pleistozänforschung in Österreich: Exkursionen zwischen Salzach und March, 82-88, 1955a.

Fink, J.: Verlauf und Ergebnisse der Quartärexkursion in Österreich 1955, Mitteilungen der Geographischen Gesellschaft Wien, 97, 209-216, 1955b. 
Fink, J.: Zur Systematik fossiler und rezenter Lößböden in Österreich, Verhandlungen VI, Internationaler Bodenkundlicher Kongress Paris, 585-592, 1956.

Fink, J. and Majdan, H.: Zur Gliederung der pleistozänen Terrassen des Wiener Raumes, Jahrbuch der Geologischen Bundesanstalt, 97, 211-249, 1954.

Freising, H.: Neue Ergebnisse der Lößforschung im nördl. Württemberg, Jahrbuch der geologischen Abteilung des württembergischen statistischen Landesamtes, 1, 54-59, 1951.

Freising, H.: Exkursionen anläßlich der Tagung der DEUQUA in Stuttgart, Wegbeschreibung und Profilskizzen (hektographiert), 1953.

Freising, H.: Gibt es in Hessen drei Würmlösse?, Jahresberichte und Mitteilungen des Oberrheinischen Geologischen Vereins, 35, 54 66, 1954.

Götzinger, G.: Zur Gliederung des Losses, Leimen- und Humuszonen im Viertel unter dem Manhartsberg, Verhandlungen der Geologischen Bundesanstalt, 8/9, 126-132, 1935.

Götzinger, G.: Das Lößgebiet um Göttweig und Krems an der Donau, Führer für die III INQUA-Kongreß in Wien, 1936.

Gullentops, F.: Contributions à la Chronologie du pleistocene et des formes du relief en Belgique, Mémoires de l'Institut Géologique de l'Université de Louvain, 18, 125-252, 1954.

Kohl, H.: Die Exkursion zwischen Lambach und Enns, Beiträge zur Pleistozänforschung in Österreich, Verhandlungen der Geologischen Bundesanstalt, Sonderheft D, 40-62, 1955.

Krivan, P.: La division climatologique du Pléistocène en Europe centrale et le profil de loess de Paks, Annales of The Geological Institute of Hungary, 43, 363-503, 1955.

Lais, R.: Über den jüngeren Löß in Niederösterreich, Mähren und Böhmen, Berichte der Naturforschenden Gesellschaft zu Freiburg im Breisgau, 41, 119-178, 1951.

Lais, R.: Über den Löß von Unterwisternitz (Mähren), Palaeohistoria, 2, 137-169, 1952.

Lascarev, V. D.: Sur la stratigraphie des dépôts quaternaires de la Vojvodina, Annales Géologiques de la Péninsule Balkanique, 19, 1951.

Markowic, J.: Contribution à la connaissance des formations quaternaires aux environs de Nis, Annales Géologiques de la Péninsule Balkanique, 19, 1951a.

Markowic, J.: Données complémentaires au problème de la tectonique de Slankamen, Bulletin du Museum d'Histoire Naturelle, 4, $1951 b$.

Markowic, J.: Les oasis du loess dans la valiée de la Morava du Sud, Bulletin du Museum d'Histoire Naturelle, 5, 1952a.

Markowic, J.: Les oasis de loess du défile de Stalac, Belgrad, 32, 1952b.

Markowic, J.: Profils de loess sur la rive droite du Danube prês du village Nestin, 1954.

Musil, R. and Valoch, K.: Über die Erforschung der Lösse in der Umgebung von Brünn (Brno) in Mähren, E\&G Quaternary Sci. J., 6, 148-151, https://doi.org/10.3285/eg.06.1.15, 1955.
Musil, R., Valoch, K., and Nečesaný, V.: Pleistocenní sedimentv okoli Brna, Anthropozoikum, 4, 1955.

Pelišek, J.: The Quaternary of the Eastern Vicinity of Brno, Anthropozoikum, 3, 7-28, 1954.

Prey, S.: Die Exkursion zwischen Vöcklabrudck und Lambach, Beiträge zur Pleistozänforschung in Österreich, Verhandlungen der Geologischen Bundesanstalt, Sonderheft D, 34-39, 1955.

Scherf, E.: Versuch einer Einteilung des ungarischen Pleistozäns auf moderner polyglazialistischer Grundlage, Verhandlungen der III, INQUA Konferenz, Wien, September 1936, 1938.

Schönhals, E.: Über einige wichtige Lößprofile und begrabene Böden im Rheingau, Notizblatt des Hessischen Landesamtes für Bodenforschung zu Wiesbaden, 6, 244-259, 1950.

Schönhals, E.: Fossile gleyartige Böden des Pleistozäns im Usinger Becken und am Rand des Vogelsberges, Notizblatt des Hessischen Landesamtes für Bodenforschung zu Wiesbaden, 6, 1951a.

Schönhals, E.: Über fossile Böden im nichtvereisten Gebiet, E\&G Quaternary Sci. J., 1, 109-130, https://doi.org/10.3285/eg.01.1.12, 1951b.

Schönhals, E.: Ergebnisse neuer Untersuchungen an Lößböden des Vogelsberges und seiner Randgebiete, Notizblatt des Hessischen Landesamtes für Bodenforschung zu Wiesbaden, 6, 1952.

Stini, H.: Zur Kenntnis jugendlicher Krustenbewegungen im Wiener Becken, Jahrbuch der Geologischen Bundesanstalt, 82, 75-102, 1932.

Troll, C.: Die jungglazialen Schotterfluren im Umkreis der Alpen, Forschungen zur deutschen Landes- und Volkskunde, 24, 158256, 1926.

Urbanek, L. and Sýkora, L.: Problems of building on Loesses and Loess-soils, Anthropozoikum, 4, 27-52, 1955.

Weinberger, L.: Über glazifluviatile Schotter bei Mauerkirchen und deren Lösse, Geologica Bavarica, 19, 231-267, 1953.

Weinberger, L.: Die Periglazial-Erscheinungen im österreichischen Teil des eiszeitlichen Salzachvorlandgletschers, Göttinger Geographische Abhandlungen, 15, 17-90, 1954.

Weinberger, L.: Exkursion durch das österr. Salzachgletschergebiet und die Moränengürtel der Irrsee- und AtterseeZweige des Traungletschers, Beiträge zur Pleistozänforschung in Österreich, Verhandlungen der Geologischen Bundesanstalt, Sonderheft D, 7-34, 1955.

Winkler von Hermaden, A.: Ergebnisse und Probleme der quartären Entwicklungsgeschichte am östlichen Alpensaum außerhalb der Vereisungsgebiet, Denkschriften der Österreichischen Akademie der Wissenschaften, 110, 197 pp., Springer, Vienna, 1955.

Woldstedt, P.: Über die Benennung einiger Unterabteilungen des Pleistozäns, E\&G Quaternary Sci. J., 3, 14-18, https://doi.org/10.3285/eg.03.1.02, 1953.

Žebera, K.: Results and tasks of the present pedological survey of the Bohemian Quaternary, Anthropozoikum, 2, 1953. 